\title{
Biodegradation of Palm-based 9,10-Dihydroxystearic Acid (DHSA) in Aquatic Environments
}

(Biodegradasi Asid 9,10-Dihidroksistearik berasaskan Sawit dalam Persekitaran Akuatik)

\author{
RAZMAH, G.,* SiTI AFIDA, I., NOORAZAH, Z. \& HAZIMAH, A.H.
}

\begin{abstract}
Palm-based DHSA is a new chemical developed in MPOB that has three reactive sites that would enable the preparation of many useful derivatives. New chemicals introduced into the market have to be registered and information on their environmental performance such as biodegradability has to be supplied as required under various national and international laws. Biodegradability screening tests, such as the OECD 301 series, are basic tools for assessment of the environmental fate of chemicals in aquatic environments. A substance is considered readily biodegradable when its biodegradability reaches the pass levels of $60 \%$ carbon dioxide $\left(\mathrm{CO}_{2}\right)$ /theoretical carbon dioxide $\left(\mathrm{ThCO}_{2}\right)$ evolution, $60 \%$ biochemical oxygen demand (BOD)/theoretical oxygen demand (ThOD) or 70\% dissolved organic carbon (DOC) removal within 28 days. Palm-based DHSA was found to be readily biodegradable where its biodegradability reached $65 \%$ within 28 days test period determined via the OECD 301C Modified MITI (I) test method, which passed the 60\% level of $B O D / T h O D$ requirement as stipulated in the OECD Guidelines for testing of chemicals. This result is indicative of DHSA's rapid degradation in aquatic environments. Hence, DHSA is not expected to accumulate in the food chains and will not pose problems in the aquatic environments although it is poorly soluble in water.
\end{abstract}

Keywords: Aquatic environments; MITI test; OECD ready biodegradability test; OECD 301C test; REACh

ABSTRAK

DHSA adalah bahan kimia baru berasaskan sawit yang dibangunkan di MPOB. Ia mempunyai tiga tapak reaktif yang membolehkan penyediaan banyak bahan terbitan berguna. Bahan kimia baru yang diperkenalkan ke dalam pasaran perlu didaftarkan dan maklumat mengenai prestasi alam sekitar mereka seperti biodegradasi perlu dibekalkan seperti yang dikehendaki di bawah pelbagai undang-undang tempatan dan antarabangsa. Ujian saringan biodegradasi, seperti siri ujian OECD 301, adalah ujian asas yang boleh digunakan untuk menilai kesan bahan kimia dalam persekitaran akuatik. Suatu bahan boleh dianggap sebagai mudah terbiodegradasi apabila peratus biodegradasinya mencapai tahap lulus $60 \%$ karbon dioksida $\left(\mathrm{CO}_{2}\right)$ /evolusi karbon dioksida teoretikal (ThCO $\left.{ }_{2}\right)$, 60\% permintaan oksigen biokimia (BOD)/ permintaan oksigen teoretikal (ThOD) atau 70\% penyingkiran karbon organik larut (DOC) dalam tempoh 28 hari. DHSA berasaskan sawit didapati mudah terbiodegradasi, dengan kadar biodegradasi mencapai 65\% dalam tempoh 28 hari yang ditentukan melalui ujian OECD 301C diubahsuai MITI (I). Nilai ini telah melepasi tahap 60\% BOD/ThOD yang diperlukan seperti yang dinyatakan di dalam garis panduan OECD bagi menguji bahan kimia. Keputusan ini adalah penunjuk kepada kemerosotan pesat DHSA dalam persekitaran akuatik. Oleh itu, DHSA dijangka tidak akan berkumpul dalam rantaian makanan dan tidak akan menimbulkan masalah dalam persekitaran akuatik meskipun ia kurang larut dalam air.

Kata kunci: Persekitaran akuatik; REACh; ujian MITI; ujian OECD sedia terbiodegradasi; ujian OECD 301C

\section{INTRODUCTION}

9, 10-dihydroxystearic acid (DHSA) can be produced from palm oil-based or palm kernel oil-based oleic acid (Roila \& Salmiah 2001). DHSA is a hydroxy fatty acid, produced from the epoxidation of oleic acid with peracetic acid or performic acid and then followed by hydrolysis of the epoxide. The resulting epoxide is hydrolyzed in an aqueous solution resulting in 9, 10-dihydroxystearic acid (Awang et al. 1998). This dihydroxy fatty acid exhibits a distinctive structure as it contains a reactive carboxylic group and two adjacent alcohol groups. These functional groups provide potential reaction sites for the preparation of many useful derivatives (Awang et al. 2009, 2007, 2006), thus found many applications in cosmetics, lubricants, detergents and soaps (Ahmad et al. 2008; Awang et al. 2001; Ismail et al. 2009, 2004).

As a potential new ingredient for various applications, evaluation of DHSA for its environmental properties is vital before its commercial use. Environmental properties data are required to fulfill various regulations set by developed countries, such as EU and US. For example, a new regulation introduced by EU in 2007, known as REACh (Registration, Evaluation, Authorization and Restriction of Chemicals), that replaces a number of European Directives 
and Regulations with a single system, requires products to be exported into EU countries to register with the European Chemical Agency (ECHA). The data needed for this registration include physico-chemical, environmental (ecotoxicological) and toxicology properties (European Commission 2013).

The evaluation of the adverse effects of raw materials used in consumer products to aquatic environment is considered important in many industries throughout the world. Today, the environmental performance of a material to be used in a consumer product is considered as important as its physical performance. The purpose for determining biodegradability in the laboratory is to predict the fate and persistence of chemicals in the environment. As required by various national and international laws, evaluation of a new chemical should include biodegradability testing as one of the important steps in its environmental assessment (Razmah \& Salmiah 2002).

Biodegradability screening tests are tools normally used in the assessment of the environmental fate of chemicals. Standardized screening tests have been used by many groups such as the industry, competent authorities and scientific organizations for many years to obtain an initial characterization of chemicals or compounds in terms of their accessibility to microbial degradation under environmental conditions. The Organization for Economic Cooperation and Development (OECD) 301 series of tests for ready biodegradability (OECD 1992) represent the most widely used biodegradation screening tests and play an important role in the EU environmental classification of chemicals and in the exposure assessment within the environmental risk assessment process.

These screening tests, even though do not simulate a specific environmental situation (a river or a sewage treatment plant), allow a general prediction of the biodegradation behavior of chemicals in the aquatic and terrestrial compartments. Due to the stringent test conditions in the OECD ready biodegradability tests, it can be assumed that chemicals meeting the pertinent biodegradation criteria will be rapidly biodegraded in the environment. On the contrary, a poor test result is not necessarily proof of their poor biodegradation under more realistic conditions (OECD 1992).

The solubility and other physico-chemical properties of the test substance determine the applicability of different test methods to assess its biodegradability. The following pass levels of biodegradation, obtained within 28 days, may be regarded as evidence of ready biodegradability: $70 \%$ dissolved organic carbon (DOC) removal (OECD 301 $\mathrm{A}$ and $301 \mathrm{E}) ; 60 \%$ theoretical carbon dioxide $\left(\mathrm{ThCO}_{2}\right)$ (OECD $301 \mathrm{~B}$ ) and $60 \%$ theoretical oxygen demand (ThOD) (OECD 301 C, 301 D and 301 F) (OECD 1992).

This paper describes the biodegradability of palmbased DHSA in aquatic environments via the OECD standard method, i.e. OECD 301C. This method is one of the seven ready biodegradable test methods under OECD 301 series. Palm-based DHSA may be considered to be readily biodegradable if the oxygen uptake as a percentage of ThOD reaches $60 \%$ of biodegradation in 28 days.

\section{MATERIALS AND METHODS}

\section{TEST SUBSTANCES}

Palm-based 9,10-dihydroxystearic acid (DHSA) was prepared in the Malaysian Palm Oil Board following the procedure developed by Awang et al. (1998). It has a molecular formula of $\mathrm{C}_{18} \mathrm{H}_{36} \mathrm{O}_{4}$ and molecular weight of $316.476 \mathrm{~g} \mathrm{~mol}^{-1}$ (Koay et al. 2011). The DHSA molecule bears three functional groups, one carboxyl and two hydroxyl groups at the $9^{\text {th }}$ and $10^{\text {th }}$ position of the C18 chain (Figure 1) (Parthiban et al. 2005).

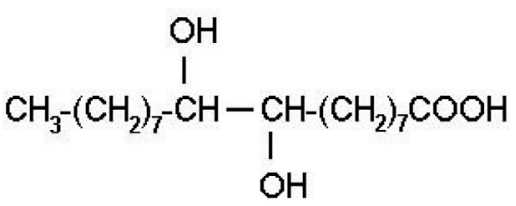

FIGURE 1 . The structure of 9,10-dihydroxystearic acid

The purity of the sample is between 85 and $95 \%$. It has been characterized by chromatographic and spectroscopic methods as well as wet chemistry. This product has a melting point of $85-90^{\circ} \mathrm{C}$, acid value of $150-170 \mathrm{mg} \mathrm{KOH} \mathrm{g}^{-1}$ sample and hydroxyl value of $280-310 \mathrm{mg} \mathrm{KOH} \mathrm{g}^{-1}$ sample. It is in solid form and not soluble in nonpolar solvent, but is soluble in dimethylsulfoxide and alcohol.

A reference compound that meets the requirement for ready biodegradability are tested by setting up an additional bottle in parallel as part of the test in order to check the procedure. Suitable reference compounds normally used are aniline, sodium acetate and sodium benzoate. These compounds are expected to degrade in the test even when no inoculum is added. Therefore, in this test, aniline (Sigma-Aldrich, USA) with more than $99.5 \%$ purity was used to check the validity of the test.

\section{TEST METHOD}

The study was conducted according to internationally recognized and widely used standard test method as described in the OECD Guidelines for the Testing of Chemicals (OECD 1992). The Modified MITI (I) test (OECD 301C) was used to determine the biodegradability of DHSA due to the suitability of this test method in analyzing poorly water-soluble compounds (OECD 1992).

The oxygen uptake by a stirred solution or suspension of the test substance in a mineral medium, inoculated with specially grown, un-adapted microorganisms, was measured continuously in an enclosed coulometer at $25 \pm 1^{\circ} \mathrm{C}$ over a period of 28 days. The coulometer is an automatic recording type respiration meter for aerobic microorganisms, developed by the Government Industrial 
Development, Hokkaido, Japan and Ohkura Electric Co. Ltd, Japan. The coulometer uses the oxygen supply system for measurement; hence liquid sample of high concentration can be measured directly without dilution. The integrated oxygen consumption was displayed digitally in units of ppm or $\mathrm{mg}$.

\section{PREPARATION OF INOCULUM}

The inoculum (sludge) used in the test was collected from at least ten sites, mainly in areas where a variety of chemicals are used and discharged, such as sewage treatment plants, industrial wastewater treatment ponds, rivers, lakes and seas (OECD 301C 1992).

The study was conducted at the Human and Environmental Safety Evaluation Center (HESEC), Lion Corporation, Japan. For this study, the activated sludge was purchased from the Chemicals Evaluation and Research Institute (CERI) of Japan, which fulfilled the requirement as stipulated in the OECD $301 \mathrm{C}$ test method. The supernatant was filtered and an appropriate volume was filled into a fill-and-draw activated sludge vessel. The supernatant was then aerated for about $23.5 \mathrm{~h}$. The aeration was then stopped for $30 \mathrm{~min}$ and approximately one third of the supernatant was discarded. An equal volume of a solution containing $0.1 \%$ each of glucose, peptone and potassium orthophosphate was added to the supernatant and the aeration was re-commenced. This process was repeated once daily until the day it was used in the test, i.e. after at least 30 day's operation.

\section{PREPARATION OF MINERAL MEDIUM STOCK SOLUTION AND TEST MEDIUM}

The following stock solutions were prepared using analytical grade reagents as in Table $1.3 \mathrm{~mL}$ of each solution $\mathrm{W}, \mathrm{X}, \mathrm{Y}$ and $\mathrm{Z}$ were mixed and made up to $1 \mathrm{~L}$ with water.

\section{PREPARATION OF BOTTLES}

The automatic coulometer was equipped with six, $300 \mathrm{~mL}$ bottles and attached with cups to place the $\mathrm{CO}_{2}$ absorbent. The 6 bottles in the coulometer were prepared as in Table 2 .

Palm-based DHSA is poorly soluble in water, therefore, the sample was added directly into the test medium on weight basis.

\section{PROCEDURE}

Bottles 2, 3 and 4 (test suspensions), 5 (activity control) and 6 (blank) of the coulometer were inoculated with inoculum at a concentration of $30 \mathrm{mg} \mathrm{l}^{-1}$ suspended solids. Bottle 1 served as an abiotic control without the addition of inoculum. The oxygen uptakes in all the bottles were measured directly using a chart recorder, which produced biochemical oxygen demand (BOD) curves.

BOD (as mg oxygen $\mathrm{mg}^{-1}$ test substance) was calculated by dividing the oxygen uptake by DHSA (mg) at an interval time, corrected with oxygen uptake by the blank at the same time, with the weight of the test substance used. This was calculated automatically by the coulometer's software.

TABLE 1. Preparation of mineral stock solutions

\begin{tabular}{clc}
\hline Solution & Chemical & Amount $(\mathrm{g})$ \\
\hline $\mathrm{W}$ & Potassium dihydrogen orthophosphate, $\mathrm{KH}_{2} \mathrm{PO}_{4}$ & 8.50 \\
& Dipotassium hydrogen orthophosphate, $\mathrm{K}_{2} \mathrm{HPO}_{4}$ & 21.75 \\
& Disodium hydrogen orthophosphate dodecahydrate, $\mathrm{Na}_{2} \mathrm{HPO}_{4} \cdot 12 \mathrm{H}_{2} \mathrm{O}$ & 44.60 \\
& Ammonium chloride, $\mathrm{NH}_{4} \mathrm{Cl}$ & 1.70 \\
& Dissolved the above in water and made up to 1 litre. & \\
& The pH value of the solution was adjusted to 7.2. & 22.50 \\
$\mathrm{X}$ & Magnesium sulphate heptahydrate, $\mathrm{MgSO}_{4} \cdot 7 \mathrm{H}_{2} 0$ & 27.50 \\
& Dissolved in water and made up to 1 litre. & \\
$\mathrm{Y}$ & Calcium chloride anhydrous, $\mathrm{CaCl} \mathrm{Cl}_{2}$ & 0.25 \\
& Dissolved in water and made up to 1 litre. & \\
$\mathrm{Z}$ & Iron (III) chloride hexahydrate, $\mathrm{FeCl}_{3} \cdot 6 \mathrm{H}_{2} 0$ & \\
& Dissolved in water and made up to 1 litre. & \\
& The pH of the solution was adjusted to 7.2. &
\end{tabular}

OECD 301C (1992)

TABLE 2. Preparation of coulometer bottles

\begin{tabular}{cl}
\hline Bottle & \multicolumn{1}{c}{ Preparation } \\
\hline 1 & DHSA in water, at $100 \mathrm{mg} \mathrm{l}^{-1}$, without sludge \\
2,3 and 4 & DHSA in mineral medium, at $100 \mathrm{mg} \mathrm{l}^{-1}$. with sludge \\
5 & Reference compound (aniline) in mineral medium, at $100 \mathrm{mg} \mathrm{l}^{-1}$, with sludge \\
6 & Mineral medium with sludge (Blank) \\
\hline
\end{tabular}




$$
\begin{aligned}
\text { BOD } & =\frac{\mathrm{mgO}_{2} \text { uptake by test substance }-\mathrm{mg} \mathrm{O}_{2} \text { uptake by blank }}{\mathrm{mg} \text { test substance in vessel }} \\
& =\mathrm{mg} \mathrm{O}_{2} \mathrm{mg}^{-1} \text { test substance. }
\end{aligned}
$$

Biodegradation is expressed as the percentage of BOD to that of the theoretical uptake (theoretical oxygen demand, ThOD) (OECD 301C 1992).

$$
\% \text { Biodegradation }=\frac{\mathrm{BOD}\left(\mathrm{mg} \mathrm{O}_{2} / \mathrm{mg} \text { substance }\right)}{\operatorname{ThOD}\left(\mathrm{mg} \mathrm{O}_{2} / \mathrm{mg} \text { substance }\right)} \times 100 \text {. }
$$

The ThOD can be calculated if the molecular formula of the compound is known, or if unknown, the elemental composition is determined via elemental analyzer. For compound,

$$
\mathrm{C}_{\mathrm{c}} \mathrm{H}_{\mathrm{h}} \mathrm{Cl}_{\mathrm{cl}} \mathrm{N}_{\mathrm{n}} \mathrm{Na}_{\mathrm{na}} \mathrm{O}_{\mathrm{o}} \mathrm{P}_{\mathrm{p}} \mathrm{S}_{\mathrm{s}}
$$

the ThOD is calculated as;

ThOD $=\frac{16[2 \mathrm{c}+1 / 2(\mathrm{~h}-\mathrm{cl}-3 \mathrm{n})+3 \mathrm{~s}+5 / 2 \mathrm{p}+1 / 2 \mathrm{na}-\mathrm{o}] \mathrm{mg} / \mathrm{mg}}{\text { molecular weight }}$.

\section{RESULTS AND DISCUSSION}

Biodegradability is an important parameter since an easily degradable substance will cause no long-term risk to the environment. Information on the degradability of chemicals may be used for hazard assessments or for risk assessments. The biodegradability screening tests measure the progress of biodegradation within 28 days via the analytical parameters of mineralization such as the evolution of carbon dioxide or consumptions of oxygen. 'Readily biodegradable' is an arbitrary classification for chemicals that have passed certain specified screening tests. In principles, any compound that surpasses the OECD ready biodegradability pass levels $\left(60 \% \mathrm{ThCO}_{2}, 60 \% \mathrm{ThOD}\right.$ or $70 \%$ DOC removal) in one of the biodegradability screening tests can be regarded as 'readily biodegradable' (OECD 1992). These tests are so stringent that it is assumed such compounds will rapidly and completely biodegrade in aquatic environments under aerobic conditions.

It is a general feature of biodegradability screening tests that the interpretation of their results are connected to threshold values above which 'ready biodegradability' or 'inherent biodegradability' can be assumed, while substances not reaching this threshold values are considered to be less biodegradable. Although the definition of such thresholds is not really scientific, it represents a practical differentiation criterion that also allows a comparison of the screening test results of an individual substance obtained in different tests.

Figures 2 and 3 show the BOD values measured from each vessel and the biodegradability of DHSA calculated using these BOD values, respectively. To check the validity of the test, the biodegradability of reference compound (aniline) was calculated after 7 days and/or 14 days. The biodegradability of aniline after 7 days should be $40 \%$ and/ or after 14 days should be $65 \%$ as stipulated in the OECD $301 \mathrm{C}$ test guideline. Reference compound is expected to degrade in the test even when no inoculum is added (OECD 1992). The percentage of biodegradability was calculated using an excel program. The biodegradability of aniline after 7 days is $64 \%$, therefore this test is considered valid.

Palm-based DHSA was biodegraded consistently (over $60 \%$ removal as indicated by oxygen consumption) within 28 days. The biodegradability of DHSA was around $27-33 \%$ after 7 days and reached $65 \%$ within 28 days of the test period (Figure 3).

No further testing was performed on this compound since it was degraded more than $60 \%$ BOD/ThOD within 28 days, which met the OECD ready biodegradability pass level

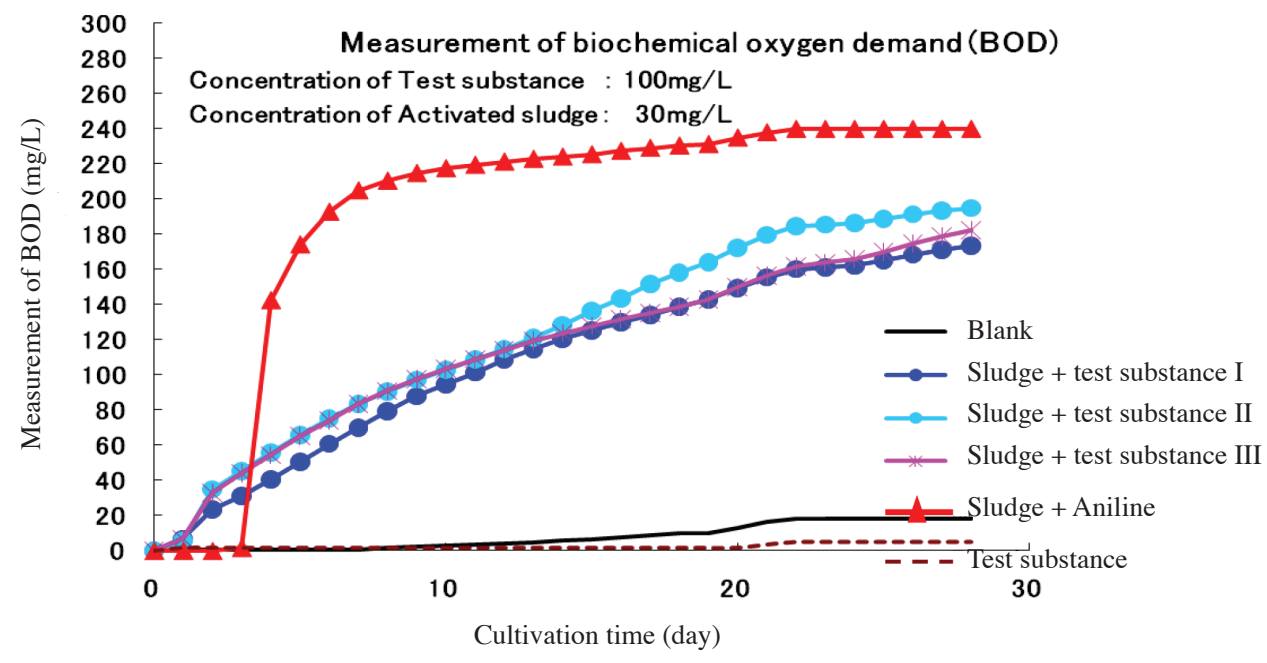

Test substance I, II and III is DHSA, test was done in triplicates

FIGURE 2. Measurement of BOD for DHSA in biodegradability test 


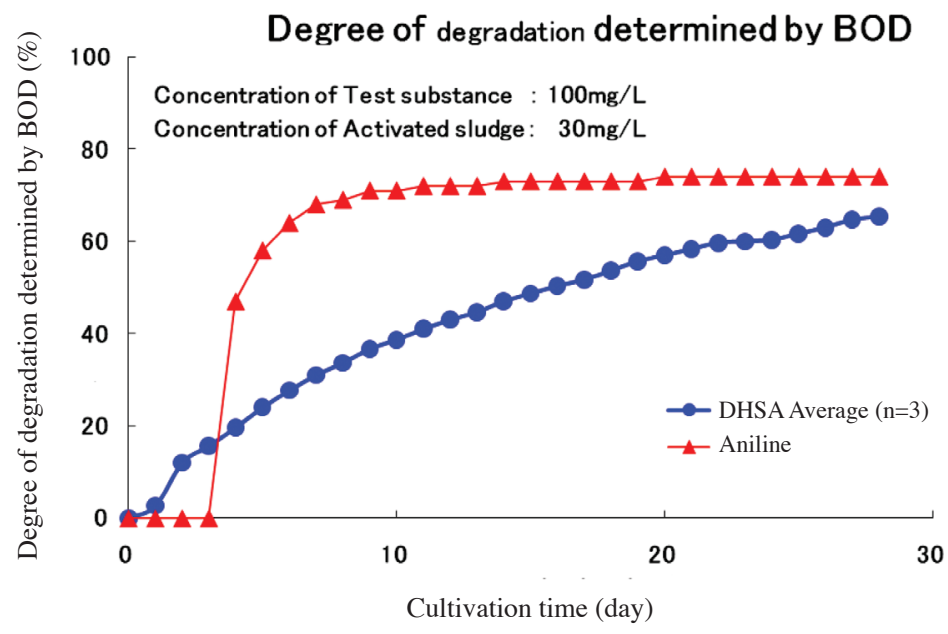

FIGURE 3. Biodegradability of DHSA and aniline calculated using BOD values

requirements. The pass level of $60 \%$ practically represents complete degradation of the test compound, while the remaining fraction of $30-40 \%$ of the test compound is assumed to be assimilated by the biomass (some of the carbons from the test compound is incorporated into new cells) or present as products of biosynthesis. Study done by Koay et al. (2011) also confirmed that palm-based DHSA is a readily biodegradable compound.

The results of a ready biodegradability test may be used for aquatic hazard classification of chemicals. According to the principles described in the 'Harmonised Integrated Classification System for Human Health and Environmental Hazards of Chemical Substances and Mixtures' (OECD 2001), a positive result in one of the OECD tests for ready biodegradability can be considered as indicative of rapid degradation in most environments. While effects can occur, particularly in the event of a spillage or accident, they will be localized and of short duration. Substances that rapidly degrade can be quickly removed from the environment.

\section{CONCLUSION}

The OECD ready biodegradability testing methods (OECD 301 series) are designed to evaluate new chemicals, such as palm-based DHSA, prior to manufacture and widespread use to ensure that these chemicals will have minimal effects on the environments. Palm-based DHSA can be considered as a readily biodegradable compound where its biodegradability reached $65 \%$ within 28 days test period determined via the OECD 301C Modified MITI (I) test method, which passed the $60 \%$ level of BOD/ ThOD requirement as stipulated in the OECD Guidelines for testing of chemicals. Due to its readily biodegradable property, palm-based DHSA will therefore be degraded within the wastewater treatment process and in the aquatic environments. Therefore, it is not expected to accumulate in the food chains and will not pose threat to the environments even though it is poorly soluble in water.

\section{ACKNOWLEDGEMENTS}

The authors would like to thank the Director-General of MPOB for permission to publish this paper and also to Mr Kousuke Yoshida and Mr Kenji Takahashi (LION Corporation, Japan) for their technical assistance.

\section{REFERENCES}

Ahmad, N., Awang, R., Ahmad, S., Ismail, R. \& Hassan, A.H. 2008. Transparent soap with dihydroxystearic acid (DHSA). Malaysian Patent Application PI 20082058.

Awang, R., Lau, T.H., Ibrahim, M.F.W.I., Basri, M. \& Ahmad, S. 2009. Monoglycerides from 9,10-dihydroxystearic acid for the cosmetic industry. J. Oil Palm Res. 21: 636-641.

Awang, R., Basri, M.,Ahmad, S. \& Salleh,A.B. 2007. Large scale production of octyl-9,10-dihydroxystearate by immobilized lipase. J. Oil Palm Res. 19: 254-263.

Awang, R., Cheong, K.W., Basri, M., Ismail, R., Ghazali, R. \& Ahmad, S. 2006. Alkanolamides from 9,10-dihydroxystearic acid. J. Oil Palm Res. 18: 231-238.

Awang, R., Ahmad, S. \& Ghazali, R. 2001. Properties of sodium soap derived from palm-based dihydroxystearic acid. J. Oil Palm Res. 13: 33-38.

Awang, R., Ahmad, S. \& Kang, Y.B. 1998. Preparation of dihydroxy fatty acid from oleic acid. Malaysian Patent PI $9,8004,456$.

European Commission. 2013. http://ec.europa.eu/enterprise/ sectors/chemicals/reach /index_en.htm.

Ismail, R., Ismail, Z., Ahmad, S., Awang, R. \& Rigano, L. 2004. Di-hydroxystearic acid, a new palm oil derivative and its esters: Properties and application in decorative cosmetics. Poster paper presented at IFSCC Congress 2004, Orlando, USA.

Ismail, R., Hassan, A.H. \& Rigano, L. 2009. Palm-derived dihydroxystearic acid for sensory and technical applications. Cosmetics \& Toiletries 124(July).

Koay, G.F., Chuah, T.G., Zainal-Abidin, S., Ahmad, S.\& Choong, T.S. 2011. Development, characterization and commercial application of palm based dihydroxystearic acid and its derivatives: An overview. J. Oleo. Sci. 60(5): 237-265.

OECD 301 C. 1992. Modified MITI Test (I). OECD guideline for testing of chemicals. OECD Publication. http://www.oecd. org/chemicalsafety/risk-assessment/1948209.pdf 
OECD. 2001. Harmonised Integrated Classification System for Human Health and Environmental Hazards of Chemical Substances and Mixtures. OECD Series on Testing and Assessment. No. 33.

OECD. 1992. OECD guideline for testing of chemicals. Ready biodegradability. OECD Publication. http://www.oecd.org/ chemicalsafety/risk-assessment/1948209.pdf

Parthiban Siwayanan, Norin Zamiah Kassim Shaari, Zulina Abd Maurad, Haliza Abd Aziz \& Salmiah Ahmad. 2005. Improved technology for the production of palm-based dihydroxystearic acid (DHSA). MPOB TT No. 282. MPOB Information Series. ISSN 1511-7871.

Razmah Ghazali \& Salmiah Ahmad. 2002. Biodegradation testing services. MPOB TT No. 144. MPOB Information Series. ISSN 1511-7871.
Roila,A. \& Salmiah,A. 2001. Dihydroxy acid derived from palmbased oleic acid. Proceeding of the 2001 PIPOC International Palm Oil Congress - Oleochemicals Conference. Bangi: MPOB. pp. 90-96.

Malaysian Palm Oil Board

6, Persiaran Institusi, Bandar Baru Bangi 43000 Kajang, Selangor Darul Ehsan Malaysia

*Corresponding author; email: razmah@mpob.gov.my

Received: 19 March 2015

Accepted: 29 May 2015 